\title{
Recent Advances in Adaptive Catchment Management and Reservoir Operation
}

\author{
Guangtao $\mathrm{Fu}^{1, *}$, Guangheng $\mathrm{Ni}^{2}$ (D) and Chi Zhang ${ }^{3}$ \\ 1 Centre for Water Systems, College of Engineering, Mathematics and Physical Sciences, University of Exeter, \\ North Park Road, Exeter, Devon EX4 4QF, UK \\ 2 Department of Hydraulic Engineering, Tsinghua University, No. 1 Qinghuayuan, Haidian, \\ Beijing 100084, China; ghni@tsinghua.edu.cn \\ 3 School of Hydraulic Engineering, Dalian University of Technology, Dalian 116023, China; \\ czhang@dlut.edu.cn \\ * Correspondence: G.Fu@exeter.ac.uk; Tel.: +44-1392-723692
}

Received: 9 February 2019; Accepted: 25 February 2019; Published: 27 February 2019

check for updates

\begin{abstract}
This editorial introduces the latest research advances in the special issue on catchment management and reservoir operations. River catchments and reservoirs play a central role in water security, community wellbeing and social-economic prosperity, but their operators and managers are under increasing pressures to meet the challenges from population growth, economic activities and changing climates in many parts of the world. This challenge is tackled from various aspects in the 27 papers included in this special issue. A synthesis of these papers is provided, focusing on four themes: reservoir dynamics and impacts, optimal reservoir operation, climate change impacts, and integrated modelling and management. The contributions are discussed in the broader context of the field and future research directions are identified to achieve sustainable and resilient catchment management.
\end{abstract}

Keywords: adaptive management; catchment modelling; integrated management; reservoir operation

\section{Introduction}

Catchment management and reservoir operation play a central role in water security, community wellbeing and social-economic prosperity. Building reservoirs, which can store water during wet periods and release it during dry periods, is an ancient approach to supply water to meet the ever growing municipal, industrial and agricultural demands and to protect communities and cities from flooding. Reservoirs are estimated to contribute directly to $12-16 \%$ of global food production as they provide irrigation for 30-40\% of a total of 268 million hectares of irrigated lands worldwide [1]. Nowadays, however, many reservoirs have to meet new demands in hydropower generation and environmental flow regulation. For example, hydropower from reservoirs is the main source of renewable, clean energy, and it accounts for about $19 \%$ of the world's electricity supply and $97 \%$ of all electricity generated from renewable sources [1,2]. Reservoir operation and management have to be considered in the context of a system of systems to address the different, often conflicting, needs of various stakeholders and their interdependency in the catchment and beyond.

The management of river catchments and reservoirs is now under increasing pressure from population growth, economic activities and changing climate means and extremes in many parts of the world. By the year 2050, the world population is expected to increase to nine billion and agricultural production will need to increase by $70 \%$ to cope with the population increase and rising food consumption [3]. This poses a huge challenge for land expansion and water withdrawals for irrigation from reservoirs. Further, the total world energy consumption has been projected to rise from 
549 quadrillion British thermal units (Btu) in 2012 to 815 quadrillion Btu in 2040, an increase of 48\% [4], of which an increasing proportion will be generated from renewable sources, including hydropower. According to the United Nations estimates, climate change could lead to an increase of $20 \%$ in water scarcity in the coming decades [5]. The above-mentioned factors place an increasing pressure on the effective management of surface water resources and environments. Adaptive management of river catchments and reservoirs is crucial to guarantee sustainability in the water-energy-food-environment nexus, which may become a major problem for sustainable development by 2050 [6,7].

Adaptive management of river catchments and reservoirs requires an in-depth understanding of the various hydrological processes and the impacts of future uncertainties, and then the development of robust, sustainable solutions to meet the needs of various stakeholders and the environment. Research shows that small perturbations in precipitation frequency and/or quantity can result in significant impacts on the discharge [8], and modest changes in natural inflows result in large changes in reservoir storage [9]. Further, the changes in the hydrologic cycle will affect energy production and water management adaptation strategies should be developed [10]. Climate change may confound water resources planning because of the deep uncertainty in the local effects [11] and the system robustness and resilience need to be fully understood [12]. Under deep uncertainty, the adaptive operational approach may prove a reliable and sustainable overall management strategy [13].

To tackle the huge challenges in moving towards adaptive catchment management, a special issue on adaptive catchment management and reservoir operation was proposed to review the latest developments in cutting-edge knowledge, novel methodologies, innovative management options and case studies in the field of water resources and catchment management. The main research of the special issues focuses on the following four themes: reservoir dynamics and their impacts on the sediment concentration in the reservoir and river, optimal operation of reservoirs, climate change impacts and integrated catchment modelling and management. These themes are covered by the 27 papers included in this special issue, as introduced in Section 2. This special issue will help researchers and practical engineers understand the current challenges in catchment and reservoir management and the current state-of-the-art knowledge and technologies employed to tackle these challenges. It will encourage managers and operators to use advanced tools for better planning and management of catchments and reservoirs, and thus improve the sustainability and resilience of water resources systems.

\section{Overview of The Special Issue}

\subsection{Reservoir Dynamics and Impacts}

The construction of dams interrupts the natural continuity of rivers; this not only alters river hydrology, hydraulics and aquatic ecology in the catchment, but also makes the reservoir itself a complex system in which various processes need to be better understood. The studies in this special issue provide an enhanced understanding of the processes within a reservoir and at the catchment scale that could be used to improve catchment and reservoir management.

The sediment deposition within reservoirs has been a key issue that affects reservoir capacity during the design life time. In China, 8 billion $\mathrm{m}^{3}$ of storage capacity of 20 large reservoirs has been lost due to sedimentation, which is $66 \%$ of the total reservoir capacity of these reservoirs [14]. The research topics in this special issue range from the loads of the sediments and the distribution of sediments in the reservoir to the sediment flushing efficiency of the reservoir. Ezz-Aldeen et al. [15] assessed the annual runoff and sediment loads of the Dokan Dam watershed using the Soil and Water Assessment Tool (SWAT) and identified the basins with a high sediment load per unit area. Chen and Tsai [16] proposed a two-dimensional bed evolution model to estimate the sediment distribution, bed evolution within a reservoir. He [17] and He et al. [18] quantified the effects of near-bed concentration on sediment flux after the construction of the reservoir. To reduce the sediments, Esmaeili et al. [19] studied the 
effects of water and discharge manipulation and the construction of an auxiliary channel on sediment flushing efficiency with a three-dimensional numerical analysis.

The construction of dams poses risks to the deterioration of upstream and downstream riverine and riparian ecosystems as they can affect the flow regimes, sediment transport, biogeochemical cycle, and downstream water temperature. Marcinkowski et al. [20] quantified the long-term downstream effects of the Siemianówka Reservoir on the river's flow regime, including the flow duration and recurrence of floods and droughts, and concluded that the upstream dam is the main driver inducing the deterioration of the anastomosing stretch of downstream. Jiang et al. [21] investigated the effects of the impoundment and the operation of the Jinghong Reservoir on downstream thermal regimes through a three-dimensional hydro- and thermodynamic model. Yang et al. [22] evaluated the impacts of water transfers on nitrogen $(\mathrm{N})$ and phosphorus $(\mathrm{P})$ uptake in the inner protection zone of the receiving reservoir of the largest inter-basin water transfer project in China, i.e., the South-to-North Water Transfer Project in China.

Recent research has confirmed that reservoirs emit a significant amount of greenhouse gas emissions, but one of the challenges is how to accurately quantify greenhouse gas emissions from individual reservoirs. Chen et al. [23] used two artificial neutral networks to estimate the total carbon dioxide emissions from the world's reservoirs and concluded that the models can be used to predict $\mathrm{CO}_{2}$ emissions from new reservoirs.

\subsection{Optimal Reservoir Operation}

The optimal design and operation of reservoirs has long been studied, but challenges remain in many areas, such as improving the search efficiency, balancing objectives and increasing system resilience, which are addressed in this special issue.

In addition to reliability and risk, there is a need to consider the performance of reservoirs from other aspects, such as vulnerability and resilience [24]. Paseka et al. [25] considered the resilience and robustness of the reservoir as key criteria to address the uncertainties from a range of future climate scenarios, and demonstrated an optimal design approach using a multipurpose reservoir with a number of objectives, including downstream environmental flow, water supply and hydropower generation. Chen et al. [26] suggested that vulnerability, which is quantified as the expected violation of the generation yield, should be considered in the optimal scheduling of hydropower generation.

In order to restore the natural stream flows and reduce the negative impacts of reservoirs, the optimal operation of the reservoirs should consider social-economic and ecological objectives. Liu et al. [27] developed the hedging rules to consider economic and ecologic objectives during reservoir operation. Zhou et al. [28] demonstrated how the joint operation of several reservoirs can effectively reduce the flood damage in several areas downstream.

New optimisation algorithms have been developed to improve the search efficiency and solution quality when optimising complex, large water resources systems. Wen et al. [29] proposed an improved differential evolution algorithm to solve the optimal operation model of the long-term scheduling of large-scale cascade hydropower stations. Uysal et al. [30] used probabilistic streamflow forecasts with a lead time of 48 hours to improve real-time flood control solutions. In the short-term operation of hydropower plants, Ji et al. [31] proposed a new progressive optimality algorithm to consider the interactions between two cascaded reservoirs. Bhatia et al. [32] used time-varying hedging policies to improve the reservoir performance, which significantly reduced the water shortage ratio and vulnerability in the case of Hemavathy Reservoir in Southern India.

\subsection{Climate Change Impacts}

Understanding the river runoff uncertainty is essential for the better adaptive management of water resources under changing environments. For the changes of historical runoff, Ye et al. [33] proposed two methods to study the quantitative relationship between daily and monthly flow duration curves. Kinouchi et al. [34] quantified the basin-scale seasonal rainfall and elucidated 
the quantitative relationship with existing climate indices. For the change of runoff in the future, Zhu et al. [35] investigated the variations of future climate and water resources availability in the Biliu River basin in the northeast China based on the downscaled climate data.

The impacts of climate change on water systems have gained a lot of attention in the past decades [36]. Abera et al. [37] assessed existing and future hydropower operation at the Tekeze Reservoir in the face of climate change. Jiang et al. [38] built a system dynamics model to simulate the evolution of the land and water resource systems in Heilongjiang Province under different climate, economic and policy scenarios.

\subsection{Integrated Modelling and Management}

Integrated catchment management has long been promoted for sustainable resource management. It recognises the complex relationships between hydrological, ecological and socio-economic systems within a catchment, and seeks to integrate different systems, models and stakeholders for water management. Zhao et al. [39] integrated a 1D water quality model and an environmental fluid dynamics model to assess the environmental capacity in the Huangshi Reservoir basin, which helped to determine the reduction targets to achieve the water quality requirements in the reservoir. An integrated model was also developed to investigate the flood risk of a key water infrastructure-the South-to-North Water Diversion project in China-and key model parameters were identified by Jin et al. [40]. Tian et al. [41] revealed that the joint operation of surface water and groundwater reservoirs is key to achieve balance among the agricultural water demand, ecological water demand and groundwater sustainability.

The impact of flooding has to be considered from an integrated perspective. Choi et al. [42] conducted a multi-scale analysis to investigate the relationships among the bitterling and mussel communities, lentic habitat structures and channel characteristics, and provided new insights into flood and sediment management at the catchment scale. The integration is also required at the stakeholder level. Indeed, effective cooperation among stakeholders was demonstrated to have a significant impact on water resource allocation in the Hanjiang River Basin through a game theory-based bi-level optimisation model [43].

\section{Conclusions}

The research articles included in this special issue addressed the challenges in catchment and reservoir management and proposed new methods, models and tools for a wide range of contemporary issues in the following themes: reservoir dynamics and impact analysis of dam construction, optimal reservoir operation, climate change impacts on hydrological processes and water management, and integrated catchment management.

With a better understanding of the interdependency and complexity of various processes and systems in a catchment, the utilization of water resources must be considered from an integrated perspective, including the integration of physical, chemical and ecological processes; integration of information and communications technology (ICT) and infrastructure [44]; and cooperation between institutions and stakeholders. Meanwhile, growing populations and economic activities increase the demands on food, energy and water, and their nexus needs to be addressed in the context of deep uncertainty arising from climate change [7,45]. To achieve sustainable and resilient catchment management, significant efforts are required from the research and practical communities to develop integrated models, new artificial intelligence tools, and robust and adaptive management options to meet the needs of various stakeholders and the environment.

Funding: This work is funded by the UK Royal Society through an international exchanges project (Ref: IEC $\backslash$ NSFC $\backslash 170249$ ) and an Industry Fellowship to the first author (Ref: IF160108).

Acknowledgments: We thank all authors for their notable contributions to this special issue and the Water editorial team for their great support during the review of the submitted manuscripts. 
Conflicts of Interest: The authors declare no conflict of interest.

\section{References}

1. The World Commission on Dams. Dams and Development: A Framework for Decision Making; Earthscan: London, UK, 2000.

2. Demirbas, A. Focus on the World: Status and Future of Hydropower. Energy Sources Part B Econ. Plan. Policy 2007, 2, 237-242. [CrossRef]

3. Bruinsma, J. The Resource Outlook to 2050: By How Much Do Land, Water and Crop Yields Need to Increase by 2050? Food and Agriculture Organization of the United Nations: Rome, Italy, 2009.

4. The US Energy Information Administration. International Energy Outlook 2016 with Projections to 2040; Energy Information Administration: Washington, DC, USA, 2016.

5. The United Nations. The United Nations World Water Development Report 2: Water-A Shared Responsibility; UN: New York, NY, USA, 2006.

6. Chen, J.; Shi, H.; Sivakumar, B.; Peart, M.R. Population, water, food, energy and dams. Renew. Sustain. Energy Rev. 2016, 56, 18-28. [CrossRef]

7. Cai, X.; Wallington, K.; Shafiee-Jood, M.; Marston, L. Understanding and managing the food-energy-water nexus-Opportunities for water resources research. Adv. Water Resour. 2018, 111, 259-273. [CrossRef]

8. Risbey, J.S.; Entekhabi, D. Observed Sacramento Basin streamflow response to precipitation and temperature changes and its relevance to climate impact studies. J. Hydrol. 1996, 184, 209-223. [CrossRef]

9. Christensen, N.S.; Wood, A.W.; Voisin, N.; Lettenmaier, D.P.; Palmer, R.N. The effects of climate change on the hydrology and water resources of the Colorado River basin. Clim. Chang. 2004, 62, 337-363. [CrossRef]

10. $\mathrm{Xu}, \mathrm{C} . ;$ Singh, V.P. Review on regional water resources assessment models under stationary and changing climate. Water Resour. Manag. 2004, 18, 591-612. [CrossRef]

11. Minville, M.; Brissette, F.; Leconte, R. Uncertainty of the impact of climate change on the hydrology of a nordic watershed. J. Hydrol. 2008, 358, 70-83. [CrossRef]

12. Casal-Campos, A.; Sadr, S.M.K.; Fu, G.; Butler, D. Reliable, Resilient and Sustainable Urban Drainage Systems: An Analysis of Robustness under Deep Uncertainty. Environ. Sci. Technol. 2018, 52, 9008-9021. [CrossRef] [PubMed]

13. Ajami, N.K.; Hornberger, G.M.; Sunding, D.L. Sustainable water resource management under hydrological uncertainty. Water Resour. Res. 2008, 44. [CrossRef]

14. Wang, Z.; Hu, C. Strategies for managing reservoir sedimentation. Int. J. Sediment Res. 2009, 24, 369-384. [CrossRef]

15. Ezz-Aldeen, M.; Hassan, R.; Ali, A.; Al-Ansari, N.; Knutsson, S. Watershed Sediment and Its Effect on Storage Capacity: Case Study of Dokan Dam Reservoir. Water 2018, 10, 858. [CrossRef]

16. Chen, C.; Tsai, C. Estimating Sediment Flushing Efficiency of a Shaft Spillway Pipe and Bed Evolution in a Reservoir. Water 2017, 9, 924. [CrossRef]

17. He, L. Quantifying the Effects of Near-Bed Concentration on the Sediment Flux after the Operation of the Three Gorges Dam, Yangtze River. Water 2017, 9, 986. [CrossRef]

18. He, L.; Chen, D.; Zhang, S.; Liu, M.; Duan, G. Evaluating Regime Change of Sediment Transport in the Jingjiang River Reach, Yangtze River, China. Water 2018, 10, 329. [CrossRef]

19. Esmaeili, T.; Sumi, T.; Kantoush, S.; Kubota, Y.; Haun, S.; Rüther, N. Three-Dimensional Numerical Study of Free-Flow Sediment Flushing to Increase the Flushing Efficiency: A Case-Study Reservoir in Japan. Water 2017, 9, 900. [CrossRef]

20. Marcinkowski, P.; Grygoruk, M. Long-Term Downstream Effects of a Dam on a Lowland River Flow Regime: Case Study of the Upper Narew. Water 2017, 9, 783. [CrossRef]

21. Jiang, B.; Wang, F.; Ni, G. Heating Impact of a Tropical Reservoir on Downstream Water Temperature: A Case Study of the Jinghong Dam on the Lancang River. Water 2018, 10, 951. [CrossRef]

22. Yang, S.; Bai, J.; Zhao, C.; Lou, H.; Wang, Z.; Guan, Y.; Zhang, Y.; Zhang, C.; Yu, X. Decline of N and P Uptake in the Inner Protection Zone of a Terminal Reservoir during Inter-Basin Water Transfers. Water 2018, 10, 178. [CrossRef]

23. Chen, Z.; Ye, X.; Huang, P. Estimating Carbon Dioxide $\left(\mathrm{CO}_{2}\right)$ Emissions from Reservoirs Using Artificial Neural Networks. Water 2018, 10, 26. [CrossRef] 
24. Zhang, C.; Xu, B.; Li, Y.; Fu, G. Exploring the relationships among reliability, resilience, and vulnerability of water supply using many-objective analysis. J. Water Resour. Plan. Manag. 2017, 143, 04017044. [CrossRef]

25. Paseka, S.; Kapelan, Z.; Marton, D. Multi-Objective Optimization of Resilient Design of the Multipurpose Reservoir in Conditions of Uncertain Climate Change. Water 2018, 10, 1110. [CrossRef]

26. Chen, C.; Kang, C.; Wang, J. Stochastic Linear Programming for Reservoir Operation with Constraints on Reliability and Vulnerability. Water 2018, 10, 175. [CrossRef]

27. Liu, Y.; Zhao, J.; Zheng, H. Piecewise-Linear Hedging Rules for Reservoir Operation with Economic and Ecologic Objectives. Water 2018, 10, 865. [CrossRef]

28. Zhou, C.; Sun, N.; Chen, L.; Ding, Y.; Zhou, J.; Zha, G.; Luo, G.; Dai, L.; Yang, X. Optimal Operation of Cascade Reservoirs for Flood Control of Multiple Areas Downstream: A Case Study in the Upper Yangtze River Basin. Water 2018, 10, 1250. [CrossRef]

29. Wen, X.; Zhou, J.; He, Z.; Wang, C. Long-Term Scheduling of Large-Scale Cascade Hydropower Stations Using Improved Differential Evolution Algorithm. Water 2018, 10, 383. [CrossRef]

30. Uysal, G.; Alvarado-Montero, R.; Schwanenberg, D.; Şensoy, A. Real-Time Flood Control by Tree-Based Model Predictive Control Including Forecast Uncertainty: A Case Study Reservoir in Turkey. Water 2018, 10, 340. [CrossRef]

31. Ji, C.; Yu, H.; Wu, J.; Yan, X.; Li, R. Research on Cascade Reservoirs' Short-Term Optimal Operation under the Effect of Reverse Regulation. Water 2018, 10, 808. [CrossRef]

32. Bhatia, N.; Srivastav, R.; Srinivasan, K. Season-Dependent Hedging Policies for Reservoir Operation-A Comparison Study. Water 2018, 10, 1311. [CrossRef]

33. Ye, L.; Ding, W.; Zeng, X.; Xin, Z.; Wu, J.; Zhang, C. Inherent Relationship between Flow Duration Curves at Different Time Scales: A Perspective on Monthly Flow Data Utilization in Daily Flow Duration Curve Estimation. Water 2018, 10, 1008. [CrossRef]

34. Kinouchi, T.; Yamamoto, G.; Komsai, A.; Liengcharernsit, W. Quantification of Seasonal Precipitation over the upper Chao Phraya River Basin in the Past Fifty Years Based on Monsoon and El Niño/Southern Oscillation Related Climate Indices. Water 2018, 10, 800. [CrossRef]

35. Zhu, X.; Zhang, C.; Qi, W.; Cai, W.; Zhao, X.; Wang, X. Multiple Climate Change Scenarios and Runoff Response in Biliu River. Water 2018, 10, 126. [CrossRef]

36. Zhang, C.; Zhu, X.; Fu, G.; Zhou, H.; Wang, H. The impacts of climate change on water diversion strategies for a water deficit reservoir. J. Hydroinform. 2014, 16, 872-889. [CrossRef]

37. Abera, F.F.; Asfaw, D.H.; Engida, A.N.; Melesse, A.M. Optimal Operation of Hydropower Reservoirs under Climate Change: The Case of Tekeze Reservoir, Eastern Nile. Water 2018, 10, 273. [CrossRef]

38. Jiang, Q.; Zhao, Y.; Wang, Z.; Fu, Q.; Wang, T.; Zhou, Z.; Dong, Y. Simulating the Evolution of the Land and Water Resource System under Different Climates in Heilongjiang Province, China. Water 2018, 10, 868. [CrossRef]

39. Zhao, F.; Li, C.; Chen, L.; Zhang, Y. An Integrated Method for Accounting for Water Environmental Capacity of the River-Reservoir Combination System. Water 2018, 10, 483. [CrossRef]

40. Jin, S.; Liu, H.; Ding, W.; Shang, H.; Wang, G. Sensitivity Analysis for the Inverted Siphon in a Long Distance Water Transfer Project: An Integrated System Modeling Perspective. Water 2018, 10, 292. [CrossRef]

41. Tian, Y.; Xiong, J.; He, X.; Pi, X.; Jiang, S.; Han, F.; Zheng, Y. Joint Operation of Surface Water and Groundwater Reservoirs to Address Water Conflicts in Arid Regions: An Integrated Modeling Study. Water 2018, 10, 1105. [CrossRef]

42. Choi, M.; Takemon, Y.; Ikeda, K.; Jung, K. Relationships Among Animal Communities, Lentic Habitats, and Channel Characteristics for Ecological Sediment Management. Water 2018, 10, 1479. [CrossRef]

43. Han, Q.; Tan, G.; Fu, X.; Mei, Y.; Yang, Z. Water Resource Optimal Allocation Based on Multi-Agent Game Theory of Hanjiang River Basin. Water 2018, 10, 1184. [CrossRef] 
44. Meng, F.; Fu, G.; Butler, D. Cost-effective River Water Quality Management using Integrated Real-Time Control Technology. Environ. Sci. Technol. 2017, 51, 9876-9886. [CrossRef] [PubMed]

45. Zhang, C.; Chen, X.; Li, Y.; Ding, W.; Fu, G. Water-energy-food nexus: Concepts, questions and methodologies. J. Clean. Prod. 2018, 195, 625-639. [CrossRef] 